\title{
The Regional Comprehensive Economic Partnership and Its Potential Impact on Greenhouse Gas Emissions
}

\author{
Hirokazu Akahori, Daisuke Sawauchi*, Yasutaka Yamamoto \\ Research Faculty of Agriculture, Hokkaido University, Sapporo, Japan \\ Email: *dsawauchi@gmail.com
}

Received 29 June 2016; accepted 12 August 2016; published 16 August 2016

Copyright (C) 2016 by authors and Scientific Research Publishing Inc.

This work is licensed under the Creative Commons Attribution International License (CC BY).

http://creativecommons.org/licenses/by/4.0/

(c) (i) Open Access

\begin{abstract}
Whether trade liberalization resulting from mega free trade agreements, such as the Regional Comprehensive Economic Partnership (RCEP), will have an impact on the environment is the subject of ongoing debate and remains an empirical matter. In this paper, we contribute to the debate on the relation between trade and the environment by considering the case of the RCEP and examining whether it will increase or decrease greenhouse gas (GHG) emissions. We measure the impact of the RCEP on GHG emissions using the Global Trade Analysis Project (GTAP) model and the GTAP $\mathrm{CO}_{2}$ and non- $\mathrm{CO}_{2}$ emissions databases. Our results suggest that the RCEP is likely to "increase" the total amount of GHG emissions in the 16 RCEP members and the world.
\end{abstract}

\section{Keywords}

RCEP, Greenhouse gas, Climate Change, GTAP

\section{Introduction}

The Regional Comprehensive Economic Partnership (RCEP) is an Association of Southeast Asian Nations (ASEAN)-centered proposal for a regional free trade area, which would initially include the ten ASEAN member states and six other countries with existing Free Trade Agreements (FTAs) with ASEAN, including Australia, China, India, Japan, the Republic of Korea, and New Zealand. Leaders from ASEAN and ASEAN's FTA partners instigated the RCEP negotiations at the East Asia Summit in Phnom Penh, Cambodia in November 2012 [1], with the 11th round of RCEP negotiations held in Brunei in February 2016.

The RCEP is one of several so-called “mega-FTAs”, including the FTAAP (Free Trade Area of the Asia Pacific), the TPP (Trans-Pacific Partnership), the TTIP (Transatlantic Trade and Investment Partnership), and the JCKFTA (Japan-China-Korea Free Trade Agreement). Together, the 16 RCEP participants account for almost half

\footnotetext{
${ }^{*}$ Corresponding author.
}

How to cite this paper: Akahori, H., Sawauchi, D. and Yamamoto, Y. (2016) The Regional Comprehensive Economic Partnership and Its Potential Impact on Greenhouse Gas Emissions. Journal of Environmental Protection, 7, 1183-1191. http://dx.doi.org/10.4236/jep.2016.79105 
of the world's population, nearly 30 percent of global GDP, and more than a quarter of world exports [1]. Thus, the RCEP could provide not only a huge economic impact, but may also exert a significant environmental impact on the RCEP region and the world.

However, whether trade liberalization resulting from mega-FTAs, such as the RCEP, will have an impact on the environment is the subject of ongoing debate and remains an empirical matter. While some existing studies address the economic impact of the RCEP [2]-[5], none concern the possible environmental impact of the RCEP.

In this paper, we contribute to the debate on the relation between trade and the environment by considering the case of the RCEP and examining whether it will increase or decrease greenhouse gas (GHG) emissions. We do this by measuring the impact of the RCEP on GHG emissions using the Global Trade Analysis Project (GTAP) model and the GTAP's $\mathrm{CO}_{2}$ and non- $\mathrm{CO}_{2}$ emissions databases.

\section{Methodology}

\subsection{Measuring the Economic Impact of the RCEP}

It is common to employ the GTAP model to provide a quantitative assessment of the economic impact of the RCEP. This is a computable general equilibrium (CGE) model developed for trade analysis by the GTAP [6]. The latest GTAP database is GTAP 9, published in 2015 and containing data on 57 industries in 140 countries and regions for three years (2004, 2007 and 2011). For our analysis, we use the standard static version of the GTAP model and the GTAP 9 database for 2011.

To facilitate comparison with other mega-FTAs (including the TPP, FTAAP, and JCKFTA), we combine the 129 countries and regions in GTAP 9 into 27 regions. We retain the original 57 industries in the database. Table 1 provides additional details on the specific regional combinations.

Our scenario assumes the complete removal of all import tariffs among the RCEP members. However, it is unlikely that the RCEP would remove all import tariffs across all sectors among the RCEP participants. In so doing, our scenario provides an upper bound of the possible economic impact of the RCEP.

\subsection{Measuring the Environmental Impact of the RCEP}

Given the limitations of the available data, we focus only on GHG emissions as the form of environmental load. We employ the GTAP $\mathrm{CO}_{2}$ emissions database and GTAP non- $\mathrm{CO}_{2}$ emissions database to measure the impact of the RCEP on GHG emissions. These databases therefore enable us to measure not only $\mathrm{CO}_{2}$ emissions, but also non- $\mathrm{CO}_{2}$ emissions, including methane $\left(\mathrm{CH}_{4}\right)$, nitrous oxide $\left(\mathrm{N}_{2} \mathrm{O}\right)$, and fluorinated GHGs (or F-gases) (namely, tetrafluorocarbon, hydrofluorocarbons, and sulfur hexafluoride).

The GTAP $9 \mathrm{CO}_{2}$ emissions database details emissions resulting only from the combustion of fossil fuels, with the levels of $\mathrm{CO}_{2}$ emissions calculated by multiplying the amount of fuel consumed by emission coefficients [7]. We assume that these emission coefficients remain unchanged with the liberalization of trade, and that the levels of $\mathrm{CO}_{2}$ emissions will therefore change in the same proportion as the levels of sectoral fuel consumption. Therefore, we calculate the post-RCEP levels of $\mathrm{CO}_{2}$ emissions by multiplying the initial level of $\mathrm{CO}_{2}$ emissions for each sector by the corresponding change in sectoral fuel consumption from the GTAP model results. For example, $\mathrm{CO}_{2}$ emissions produced by coal use in the electricity sector is calculated by multiplying the initial levels of $\mathrm{CO}_{2}$ emissions resulting from coal use in electricity sector by the change in coal use in electricity sector derived from the GTAP results.

The GTAP 9 non- $\mathrm{CO}_{2}$ emissions database provides the emissions data for three major non- $\mathrm{CO}_{2}$ gases $\left(\mathrm{CH}_{4}\right.$, $\mathrm{N}_{2} \mathrm{O}$, and F-gases) [8]. In this database, the levels for each type of non- $\mathrm{CO}_{2}$ emissions are associated with output, endowment use, and input use by industry and private households [9]. We assume that the levels of non- $\mathrm{CO}_{2}$ gases change in the same proportion as the corresponding GTAP variables. This assumption allows us to calculate the post-RCEP level of non- $\mathrm{CO}_{2}$ gases by multiplying the initial level of non- $\mathrm{CO}_{2}$ emissions by the corresponding sectoral changes derived from the GTAP results. For example, the paddy rice sector emits $\mathrm{CH}_{4}$. We then calculate the post-RCEP level of $\mathrm{CH}_{4}$ emissions from land use in the paddy rice sector by multiplying the initial $\mathrm{CH}_{4}$ emissions by the change in land use for paddy rice derived from the GTAP results.

\section{Results}

\subsection{The Economic Impact of the RCEP}

Table 2 details the impact of the RCEP on real GDP, total exports, and total imports. As shown, under full trade 
Table 1. Regions and sectors.

\begin{tabular}{|c|c|c|c|c|c|}
\hline & Region & & Sector & & Sector \\
\hline 1 & Japan & 1 & Paddy rice & 30 & Wood products \\
\hline 2 & Korea & 2 & Wheat & 31 & Paper products, publishing \\
\hline 3 & China & 3 & Cereal grains nec ${ }^{\mathrm{d}}$ & 32 & Petroleum, coal products \\
\hline 4 & Indonesia & 4 & Vegetables, fruit, nuts & 33 & Chemicals \\
\hline 5 & Malaysia & 5 & Oil seeds & 34 & Mineral products nec ${ }^{\mathrm{d}}$ \\
\hline 6 & Philippines & 6 & Sugar cane, sugar beet & 35 & Ferrous metals \\
\hline 7 & Singapore & 7 & Plant-based fibers & 36 & Metals nec ${ }^{\mathrm{d}}$ \\
\hline 8 & Thailand & 8 & Crops nec ${ }^{\mathrm{d}}$ & 37 & Metal products \\
\hline 9 & Vietnam & 9 & Cattle & 38 & Motor vehicles and parts \\
\hline 10 & Cambodia & 10 & Animal products nec ${ }^{d}$ & 39 & Transport equipment nec ${ }^{\mathrm{d}}$ \\
\hline 11 & Laos & 11 & Raw milk & 40 & Electronic equipment \\
\hline 12 & Brunei & 12 & Wool, silkworm cocoons & 41 & Machinery and equipment nec ${ }^{\mathrm{d}}$ \\
\hline 13 & Other ASEAN ${ }^{\mathrm{a}}$ & 13 & Forestry & 42 & Manufactures nec ${ }^{\mathrm{d}}$ \\
\hline 14 & India & 14 & Fishing & 43 & Electricity \\
\hline 15 & Australia & 15 & Coal & 44 & Gas manufacture, distribution \\
\hline 16 & New Zealand & 16 & Oil & 45 & Water \\
\hline 17 & United States & 17 & Gas & 46 & Construction \\
\hline 18 & Canada & 18 & Minerals nec ${ }^{d}$ & 47 & Trade \\
\hline 19 & Mexico & 19 & Meat: cattle, sheep, goats, horse & 48 & Transport nec ${ }^{\mathrm{d}}$ \\
\hline 20 & Peru & 20 & Meat products nec ${ }^{\mathrm{d}}$ & 49 & Sea transport \\
\hline 21 & Chile & 21 & Vegetable oils and fats & 50 & Air transport \\
\hline 22 & Hong Kong & 22 & Dairy products & 51 & Communication \\
\hline 23 & Taiwan & 23 & Processed rice & 52 & Financial services nec ${ }^{\mathrm{d}}$ \\
\hline 24 & Russia & 24 & Sugar & 53 & Insurance \\
\hline 25 & EU27 & 25 & Food products nec ${ }^{\mathrm{d}}$ & 54 & Business services nec ${ }^{\mathrm{d}}$ \\
\hline 26 & ROW $^{\mathrm{b}}$ & 26 & Beverages and tobacco products & 55 & Recreation and other services \\
\hline \multirow[t]{3}{*}{27} & ROW $^{c}$ & 27 & Textiles & 56 & Pub Admin/Defence/Health/Education \\
\hline & & 28 & Wearing apparel & 57 & Dwellings \\
\hline & & 29 & Leather products & & \\
\hline
\end{tabular}

a. Other ASEAN includes Myanmar and Timor-Leste. b. ROW1 includes rest of Asian economies. c. ROW2 includes rest of the world. d. nec means not elsewhere classified.

liberalization, the 16 participants are likely to experience a positive average impact of the RCEP on real GDP, total exports, and total imports, which increase by $0.19 \%, 2.95 \%$, and $5.19 \%$, respectively. In contrast, nonRCEP economies other than Russia are likely to experience a negative impact on real GDP. In percentage terms, the increase in Vietnam is the highest across GDP (0.91\%), and the increases in Cambodia are the highest across total exports (8.96\%) and total imports (10.31\%).

By way of a comparison, reference [2] analyzed the economic effects of an ASEAN + 6 (Japan, China, Korea, Australia, New Zealand, and India) FTA (effectively the RCEP) using the GTAP model and the GTAP 6 database (corresponding to 2001). Reference [2] showed that the ASEAN + 6 FTA, under a full liberalization scenario, also had a positive impact on the real GDP, exports, and imports of the ASEAN + 6 countries. 
Table 2. Economic impact of RCEP (\%).

\begin{tabular}{|c|c|c|c|}
\hline & Real GDP & Total export & Total import \\
\hline 16 RCEP members & 0.19 & 2.95 & 5.19 \\
\hline Japan & 0.15 & 1.39 & 6.19 \\
\hline Korea & 0.73 & 3.31 & 6.63 \\
\hline China & 0.09 & 3.55 & 4.46 \\
\hline Indonesia & 0.06 & 2.66 & 3.90 \\
\hline Malaysia & 0.37 & 1.94 & 4.25 \\
\hline Philippines & 0.08 & 2.52 & 1.62 \\
\hline Singapore & 0.06 & 0.45 & 1.95 \\
\hline Thailand & 0.39 & 3.05 & 6.53 \\
\hline Vietnam & 0.91 & 0.64 & 10.20 \\
\hline Cambodia & 0.56 & 8.96 & 10.31 \\
\hline Laos & 0.36 & 5.32 & 8.31 \\
\hline Brunei & 0.08 & -0.33 & 1.84 \\
\hline Other ASEAN ${ }^{\mathrm{a}}$ & 0.06 & 6.99 & 3.18 \\
\hline India & 0.41 & 8.32 & 5.07 \\
\hline Australia & 0.11 & 0.99 & 6.09 \\
\hline New Zealand & 0.05 & 0.66 & 2.15 \\
\hline United States & -0.01 & 0.71 & -1.04 \\
\hline Canada & -0.01 & 0.32 & -0.14 \\
\hline Mexico & -0.01 & 0.27 & -0.03 \\
\hline Peru & -0.00 & 0.16 & -0.54 \\
\hline Chile & -0.01 & 0.24 & -0.26 \\
\hline Hong Kong & -0.00 & -0.01 & -0.77 \\
\hline Taiwan & -0.04 & -0.44 & -1.71 \\
\hline Russia & 0.01 & 0.24 & -0.60 \\
\hline EU27 & -0.01 & 0.23 & -0.26 \\
\hline ROW $^{\text {b }}$ & -0.06 & 0.21 & -1.15 \\
\hline $\mathrm{ROW}^{\mathrm{c}}$ & -0.02 & 0.05 & -0.51 \\
\hline
\end{tabular}

a. Other ASEAN includes Myanmar and Timor-Leste. b. ROW1 includes rest of Asian economies. c. ROW2 includes rest of the world.

Table 3 provides details of the impact of the sectoral output changes in percentage terms. Throughout the following discussion, we focus on Japan, China, and India, as the three largest RCEP members (in terms of real GDP), Australia, given its greatest growth in non- $\mathrm{CO}_{2}$ emissions, as shown later in Table 4, and the United States (US) and the European Union (EU) as key non-RCEP-member economies.

As shown in Table 3, with full trade liberalization among the RCEP participants, farm output (defined as the agricultural sectors from paddy rice to wool, silkworm cocoons) tends to decline in Japan, but increases somewhat in China and Australia. In percentage terms, the decline rate in output from the paddy rice sector $(-29.51 \%)$ is the most significant decline rate of all the sectoral output changes in Japan. In contrast, the increase rate in output 
Table 3. Impact on sectoral outputs (\%).

\begin{tabular}{|c|c|c|c|c|c|c|}
\hline & Japan & China & India & Australia & United States & EU27 \\
\hline Farm output & -7.96 & 0.19 & -0.41 & 11.82 & -0.46 & -0.03 \\
\hline Paddy rice & -29.51 & 1.55 & 1.57 & 32.90 & -1.40 & 2.22 \\
\hline Wheat & -4.26 & -0.60 & 0.70 & -5.95 & 0.69 & 0.05 \\
\hline Cereal grains nec ${ }^{a}$ & -0.53 & 0.75 & 7.65 & 43.07 & -0.69 & -0.07 \\
\hline Vegetables, fruit, nuts & -0.87 & 0.65 & -0.06 & -0.19 & -0.44 & 0.04 \\
\hline Oil seeds & -13.03 & 1.23 & -11.71 & -1.04 & -1.19 & -0.15 \\
\hline Sugar cane, sugar beet & -2.10 & -6.07 & 0.72 & 12.55 & 0.04 & -0.01 \\
\hline Plant-based fibers & 2.01 & 0.27 & 3.35 & -3.90 & -0.21 & -0.69 \\
\hline Crops nec ${ }^{\mathrm{a}}$ & -3.14 & 10.47 & -1.42 & -5.62 & -0.11 & 0.01 \\
\hline Cattle & -13.17 & 0.25 & 0.13 & 14.83 & -0.59 & 0.20 \\
\hline Wool, silkworm cocoons & 1.14 & -27.39 & 1.23 & 91.83 & -8.89 & -24.38 \\
\hline Electricity & 0.39 & -0.07 & 0.20 & -0.26 & -0.00 & -0.00 \\
\hline
\end{tabular}

a. nec means not elsewhere classified.

from the paddy rice sector is the second most significant increase rate of all sectoral output changes in China (1.55\%) and the third most significant increase rate in Australia (32.90\%). Electricity sector output, one of the largest sources of $\mathrm{CO}_{2}$ emissions, increases in Japan, India, and decreases in China, Australia, the US, and the EU.

Regarding the ASEAN + 6 FTA, reference [2] found that Japan was likely to experience a decrease in output in the agricultural and food sectors, while China and Australia were likely to experience an increase. With respect to the JCKFTA, reference [10] showed that Japan was likely to experience a decrease in output in the paddy rice sector, whereas China was likely to experience an increase.

\subsection{The Environmental Impact of the RCEP}

Table 4 details the impact of the RCEP on GHG emissions. All figures are in million metric tons (Mt) of $\mathrm{CO}_{2}$ equivalent. We first focus on the results for the 16 RCEP members and the world. As shown, the RCEP is likely to increase the total amounts of GHG emissions in both the 16 RCEP members and the world, with total GHG emissions of the RCEP and the world increasing by $19.32 \mathrm{Mt} \mathrm{CO}_{2}$ eq. (0.11\%) and $25.10 \mathrm{Mt} \mathrm{CO}_{2}$ eq. (0.06\%), respectively. As for our main research question, these GHG emission impact results show that the RCEP is likely to "increase" the total amount of GHG emissions in the 16 RCEP members and the world.

In other findings, the total $\mathrm{CO}_{2}$ emissions of the 16 RCEP members and the world will increase by $7.08 \mathrm{Mt}$ $\mathrm{CO}_{2}$ eq. $(0.06 \%)$ and $10.38 \mathrm{Mt} \mathrm{CO}_{2}$ eq. (0.04\%), respectively, and the total non- $\mathrm{CO}_{2}$ emissions of the $16 \mathrm{RCEP}$ members and the world will increase by $12.24 \mathrm{Mt} \mathrm{CO}_{2}$ eq. (0.23\%) and $14.72 \mathrm{Mt} \mathrm{CO}_{2}$ eq. (0.12\%), respectively. Among the non-RCEP members, the total GHG emissions of the US will decrease by $0.23 \mathrm{Mt} \mathrm{CO}_{2}$ eq. (less than $0.01 \%$ ), while those of the EU will increase by $6.55 \mathrm{Mt} \mathrm{CO}_{2}$ eq. (0.14\%).

We next focus on the results for the individual economies. In terms of $\mathrm{CO}_{2}$ emissions, Japan and Korea will experience the greatest and the third greatest increase of all the economies, with the sum of its increases in $\mathrm{CO}_{2}$ emissions (5.59 $\mathrm{Mt} \mathrm{CO}_{2}$ eq. and $4.14 \mathrm{Mt} \mathrm{CO}_{2}$ eq.) almost equaling the increase across all 16 RCEP members (7.08 $\mathrm{Mt} \mathrm{CO}_{2}$ eq.) and the world (10.38 $\mathrm{Mt} \mathrm{CO}_{2}$ eq.).

In terms of non- $\mathrm{CO}_{2}$ emissions for the individual economies, Australia will experience the greatest increase (11.92 $\mathrm{Mt} \mathrm{CO}_{2}$ eq.), which is almost equal to the increase across all $16 \mathrm{RCEP}$ members (12.24 $\mathrm{Mt} \mathrm{CO}_{2}$ eq.). In percentage terms, New Zealand has the highest rate of increase in non- $\mathrm{CO}_{2}$ emissions (5.00\%), while the Philippines has the largest rate of decrease (-3.45\%).

Table 5 identifies the industrial sectors that contribute most in terms of $\mathrm{CO}_{2}, \mathrm{CH}_{4}$, and $\mathrm{N}_{2} \mathrm{O}$ emissions. We selected the top five sectors by the absolute change in each emission. We omitted F-gases from the table because 
Table 4. Impact on GHG emissions ( $\mathrm{Mt} \mathrm{CO}_{2}$ equivalent, $\%{ }^{\mathrm{a}}$ ).

\begin{tabular}{|c|c|c|c|c|c|c|}
\hline \multirow[b]{2}{*}{16 RCEP members } & \multicolumn{2}{|c|}{$\mathrm{CO}_{2}$} & \multicolumn{2}{|c|}{ Non- $\mathrm{CO}_{2}$} & \multicolumn{2}{|c|}{ GHG } \\
\hline & 7.08 & $(\mathbf{0 . 0 6 )}$ & 12.24 & $(0.23)$ & 19.32 & $(0.11)$ \\
\hline Japan & 5.59 & $(0.54)$ & -2.69 & $(-2.97)$ & 2.90 & $(0.26)$ \\
\hline Korea & 4.14 & $(0.83)$ & 0.18 & $(0.35)$ & 4.32 & $(0.78)$ \\
\hline China & -0.86 & $(-0.01)$ & 2.64 & $(0.10)$ & 1.78 & $(0.02)$ \\
\hline Indonesia & -1.45 & $(-0.37)$ & -0.60 & $(-0.18)$ & -2.05 & $(-0.29)$ \\
\hline Malaysia & -0.49 & $(-0.24)$ & -0.20 & $(-0.39)$ & -0.69 & $(-0.27)$ \\
\hline Philippines & 0.07 & $(0.09)$ & -2.78 & $(-3.45)$ & -2.71 & $(-1.70)$ \\
\hline Singapore & 0.43 & $(0.65)$ & 0.22 & $(2.81)$ & 0.65 & $(0.88)$ \\
\hline Thailand & -0.10 & $(-0.04)$ & 2.68 & $(2.02)$ & 2.58 & $(0.69)$ \\
\hline Vietnam & 1.57 & $(1.24)$ & -0.60 & $(-0.41)$ & 0.97 & $(0.35)$ \\
\hline Cambodia & 0.41 & $(8.61)$ & -0.43 & $(-1.47)$ & -0.02 & $(-0.06)$ \\
\hline Laos & 0.11 & $(5.66)$ & -0.20 & $(-1.67)$ & -0.10 & $(-0.68)$ \\
\hline Brunei & -0.06 & $(-0.72)$ & -0.04 & $(-0.83)$ & -0.10 & $(-0.76)$ \\
\hline Other ASEAN ${ }^{\mathrm{b}}$ & 0.02 & $(0.21)$ & 0.79 & $(0.76)$ & 0.81 & $(0.72)$ \\
\hline India & -2.07 & $(-0.12)$ & -0.76 & $(-0.06)$ & -2.83 & $(-0.09)$ \\
\hline Australia & -0.28 & $(-0.07)$ & 11.92 & $(4.46)$ & 11.64 & $(1.80)$ \\
\hline New Zealand & 0.05 & $(0.16)$ & 2.12 & $(5.00)$ & 2.17 & $(2.90)$ \\
\hline United States & -0.17 & $(-0.00)$ & -0.06 & $(-0.01)$ & -0.23 & $(-0.00)$ \\
\hline Canada & 0.19 & $(0.04)$ & -0.57 & $(-0.35)$ & -0.38 & $(-0.06)$ \\
\hline Mexico & -0.02 & $(-0.01)$ & -0.53 & $(-0.30)$ & -0.55 & $(-0.09)$ \\
\hline Peru & 0.04 & $(0.08)$ & -0.03 & $(-0.07)$ & 0.01 & $(0.01)$ \\
\hline Chile & 0.16 & $(0.20)$ & -0.05 & $(-0.18)$ & 0.10 & $(0.10)$ \\
\hline Hong Kong & 0.17 & $(0.20)$ & 0.00 & $(-0.04)$ & 0.17 & $(0.19)$ \\
\hline Taiwan & -1.38 & $(-0.56)$ & -0.05 & $(-0.28)$ & -1.43 & $(-0.54)$ \\
\hline Russia & -0.32 & $(-0.02)$ & 0.32 & $(0.04)$ & 0.00 & $(-0.00)$ \\
\hline EU27 & 4.23 & $(0.12)$ & 2.32 & $(0.21)$ & 6.55 & $(0.14)$ \\
\hline ROW $^{\mathrm{c}}$ & 0.09 & $(0.03)$ & -0.41 & $(-0.08)$ & -0.32 & $(-0.04)$ \\
\hline ROW2 $^{\mathrm{d}}$ & 0.31 & $(0.01)$ & 1.55 & $(0.04)$ & 1.86 & $(0.02)$ \\
\hline World & 10.38 & $(0.04)$ & 14.72 & $(0.12)$ & 25.10 & $(0.06)$ \\
\hline
\end{tabular}

a. Figures in parentheses are percentage deviations from the initial period. b. Other ASEAN includes Myanmar and Timor-Leste. c. ROW1 includes rest of Asian economies. d. ROW2 includes rest of the world.

relatively few sectors emit these GHGs. In terms of $\mathrm{CO}_{2}$ emissions, non-agricultural sectors appear in the top five sectors. Four of six economies in Table 5 have an electricity sector.

In terms of work elsewhere, reference [11] assessed the impact of a regional trade agreement that decreased import tariffs among the six East Asian countries (Japan, Korea, China, Indonesia, Thailand, and Vietnam), also selecting the top five sectors according to the absolute change for each of the GHGs. They also showed that in all six of the countries they analyzed, the electricity sector was one of the major $\mathrm{CO}_{2}$ emitters. 
Table 5. Most affected sectors by country for GHG emissions ( $\mathrm{Mt} \mathrm{CO}_{2}$ equivalent, ${ }^{\mathrm{a}}{ }^{\mathrm{a}}$ ).

\begin{tabular}{|c|c|c|c|c|c|c|c|}
\hline Japan & \multicolumn{2}{|c|}{$\mathrm{CO}_{2}$} & \multicolumn{4}{|c|}{$\mathrm{CH}_{4}$} & $\mathrm{~N}_{2} \mathrm{O}$ \\
\hline Electricity & 1.84 & $(0.40)$ & Paddy rice & -1.05 & $(-15.21)$ & Paddy rice & $-0.30 \quad(-29.51)$ \\
\hline Mineral products nec ${ }^{\mathrm{b}}$ & 0.48 & $(2.06)$ & Cattle & -0.51 & $(-15.29)$ & Cattle & $-0.26 \quad(-15.21)$ \\
\hline Ferrous metals & 0.47 & $(1.16)$ & Raw milk & -0.20 & $(-12.06)$ & Raw milk & $-0.06 \quad(-11.76)$ \\
\hline Air transport & -0.28 & $(-1.90)$ & Animal products nec ${ }^{\mathrm{b}}$ & -0.06 & $(-1.35)$ & Crops nec ${ }^{\mathrm{b}}$ & $-0.03 \quad(-3.14)$ \\
\hline Petroleum, coal products & 0.21 & $(0.78)$ & PADHE $^{\mathrm{C}}$ & 0.01 & $(0.14)$ & Animal products nec ${ }^{\mathrm{b}}$ & $-0.02 \quad(-1.15)$ \\
\hline China & \multicolumn{2}{|c|}{$\mathrm{CO}_{2}$} & \multicolumn{4}{|c|}{$\mathrm{CH}_{4}$} & $\mathrm{~N}_{2} \mathrm{O}$ \\
\hline Mineral products nec ${ }^{\mathrm{b}}$ & 1.81 & $(0.32)$ & Paddy rice & 1.16 & $(0.99)$ & Vegetables, fruit, nuts & $1.07 \quad(0.65)$ \\
\hline Chemicals & -1.73 & $(-0.65)$ & Cattle & 0.78 & $(0.43)$ & Cattle & $(0.43)$ \\
\hline Ferrous metals & -1.00 & $(-0.24)$ & Wool, silkworm cocoons & -0.41 & $(-27.39)$ & Animal products nec ${ }^{\mathrm{b}}$ & $0.39 \quad(0.62)$ \\
\hline Electricity & -1.00 & $(-0.02)$ & $\mathrm{PADHE}^{\mathrm{c}}$ & -0.38 & $(-0.10)$ & Paddy rice & $0.36 \quad(1.55)$ \\
\hline Textiles & 0.61 & $(2.60)$ & Animal products nec ${ }^{\mathrm{b}}$ & 0.26 & $(0.58)$ & Crops nec ${ }^{\mathrm{b}}$ & $0.17 \quad(10.47)$ \\
\hline India & \multicolumn{2}{|c|}{$\mathrm{CO}_{2}$} & \multicolumn{4}{|c|}{$\mathrm{CH}_{4}$} & $\mathrm{~N}_{2} \mathrm{O}$ \\
\hline Electricity & -2.04 & $(-0.21)$ & Paddy rice & 1.71 & $(1.72)$ & Oil seeds & $-1.54(-11.70)$ \\
\hline Vegetable oils and fats & -0.46 & $(-43.18)$ & PADHE $^{\mathrm{c}}$ & -0.84 & $(-0.48)$ & Cereal grains nec ${ }^{\mathrm{b}}$ & $0.60 \quad(7.65)$ \\
\hline Chemicals & 0.44 & $(0.98)$ & Oil seeds & -0.62 & $(-11.70)$ & Crops nec ${ }^{\mathrm{b}}$ & $-0.52 \quad(-1.41)$ \\
\hline Mineral products nec ${ }^{\mathrm{b}}$ & -0.38 & $(-0.39)$ & Cattle & -0.32 & $(-0.12)$ & Plant-based fibers & (3.35) \\
\hline Transport nec ${ }^{\mathrm{b}}$ & 0.36 & $(0.24)$ & Cereal grains nec ${ }^{b}$ & 0.31 & (7.65) & Wheat & $0.23 \quad(0.70)$ \\
\hline Australia & \multicolumn{2}{|c|}{$\mathrm{CO}_{2}$} & \multicolumn{4}{|c|}{$\mathrm{CH}_{4}$} & $\mathrm{~N}_{2} \mathrm{O}$ \\
\hline Electricity & -0.50 & $(-0.26)$ & Cattle & 8.68 & $(17.78)$ & Cattle & $5.50 \quad(17.72)$ \\
\hline Wool, silkworm cocoons & 0.48 & $(91.86)$ & Cereal grains nec ${ }^{b}$ & 1.46 & $(27.57)$ & Cereal grains nec ${ }^{b}$ & $2.33 \quad(29.23)$ \\
\hline Air transport & -0.44 & $(-2.07)$ & Wheat & -0.98 & $(-10.26)$ & Wheat & $-1.42 \quad(-9.78)$ \\
\hline Metals nec ${ }^{\mathrm{b}}$ & -0.21 & $(-1.79)$ & Vegetables, fruit, nuts & -0.59 & $(-5.71)$ & Vegetables, fruit, nuts & $-0.80 \quad(-5.14)$ \\
\hline Ferrous metals & -0.19 & $(-4.69)$ & Plant-based fibers & -0.45 & $(-8.66)$ & Plant-based fibers & $-0.63 \quad(-8.32)$ \\
\hline United States & \multicolumn{2}{|c|}{$\mathrm{CO}_{2}$} & \multicolumn{4}{|c|}{$\mathrm{CH}_{4}$} & $\mathrm{~N}_{2} \mathrm{O}$ \\
\hline Air transport & 1.49 & $(0.41)$ & Cattle & -0.80 & $(-0.78)$ & Cattle & $-0.40 \quad(-0.77)$ \\
\hline Transport nec ${ }^{\mathrm{b}}$ & 0.65 & $(0.10)$ & Coal & 0.17 & $(0.22)$ & Cereal grains nec ${ }^{\mathrm{b}}$ & $-0.25 \quad(-0.69)$ \\
\hline Chemicals & 0.20 & $(0.18)$ & Raw milk & -0.15 & $(-0.44)$ & Oil seeds & $-0.18 \quad(-1.18)$ \\
\hline Ferrous metals & 0.18 & $(0.49)$ & Animal products nec ${ }^{\mathrm{b}}$ & -0.12 & $(-0.44)$ & Chemicals & $(0.17)$ \\
\hline Sea transport & 0.15 & $(0.37)$ & Paddy rice & -0.06 & $(-0.79)$ & Animal products nec ${ }^{b}$ & $-0.08 \quad(-0.40)$ \\
\hline EU27 & \multicolumn{2}{|c|}{$\mathrm{CO}_{2}$} & \multicolumn{4}{|c|}{$\mathrm{CH}_{4}$} & $\mathrm{~N}_{2} \mathrm{O}$ \\
\hline Sea transport & 2.64 & $(1.63)$ & Cattle & 0.21 & $(0.20)$ & Cattle & $(0.20)$ \\
\hline Transport nec ${ }^{\mathrm{b}}$ & 1.95 & $(0.29)$ & Raw milk & -0.15 & $(-0.22)$ & Raw milk & $-0.05 \quad(-0.22)$ \\
\hline Air transport & 0.96 & $(0.49)$ & Transport nec ${ }^{\mathrm{b}}$ & 0.14 & $(0.29)$ & Wool, silkworm cocoons & $-0.03 \quad(-24.38)$ \\
\hline Petroleum, coal products & 0.19 & $(0.15)$ & Coal & 0.12 & $(0.25)$ & Oil seeds & $-0.02 \quad(-0.15)$ \\
\hline Mineral products nec ${ }^{\mathrm{b}}$ & -0.17 & $(-0.21)$ & Paddy rice & 0.09 & $(1.84)$ & Petroleum, coal products & $0.01 \quad(0.17)$ \\
\hline
\end{tabular}

a. Figures in parentheses are percentage deviations from the initial period. b. nec means not elsewhere classified. c. PADHE is PubAdmin/Defence/Health/Education.

Regarding $\mathrm{CH}_{4}$ emissions, we observe a significant increase in the volume of emissions in the cattle sector in Australia (8.68 $\mathrm{Mt} \mathrm{CO}_{2}$ eq.), whereas in percentage terms $\mathrm{CH}_{4}$ emissions from the cattle sector decreased most significantly in Japan $(-15.29 \%)$. These particular results mainly arise because of the large increase in output from the cattle sector in Australia and the large decrease in output from the cattle sector in Japan, as shown in 
Table 3. In Japan, the paddy rice sector also shows the significant decrease $\left(-1.05 \mathrm{Mt} \mathrm{CO}_{2}\right.$ eq.). All six economies in Table 5 also have a cattle sector, while all six economies other than Australia also have a paddy rice sector. Reference [11] also found that in all six countries they analyzed, the paddy rice sector was one of the top five $\mathrm{CH}_{4}$-emitting sectors.

As for $\mathrm{N}_{2} \mathrm{O}$ emissions, we identify a significant increase in emissions from the cattle sector in Australia (5.50 $\mathrm{Mt} \mathrm{CO}_{2}$ eq.), while in percentage terms the decrease in these same emissions is the second largest in Japan $(-15.21 \%)$. Once again, these results are due to the large increase in output from the cattle in Australia and the large decreases in output from the cattle sector in Japan, as shown in Table 3. Five economies in Table 5 other than India also include the cattle sector in their top five sectors.

For both $\mathrm{CH}_{4}$ and $\mathrm{N}_{2} \mathrm{O}$ emissions, three or more of the top five emitting sectors in each economy are farm sectors. Worldwide in 2005, while $\mathrm{CO}_{2}$ emissions are concentrated in the energy sector, agriculture accounts for the largest share of non- $\mathrm{CO}_{2}$ emissions [12]. In sum, our results show that the RCEP is likely to increase the total amount of GHG emissions for both the 16 RCEP members and the world.

\section{Conclusions}

In this paper, we contribute to the debate on the relation between trade and the environment by considering the case of the RCEP and examining whether it will increase or decrease GHG emissions. To respond to this important research question, we measure the impact of the RCEP on GHG emissions using the GTAP model and the GTAP $\mathrm{CO}_{2}$ and non- $\mathrm{CO}_{2}$ emissions databases. Our scenario assumes the complete removal of all import tariffs among the RCEP members.

The results in terms of economic impact show that the 16 RCEP participants are likely to experience a positive effect on real GDP. In contrast, non-RCEP economies other than Russia are likely to experience a negative impact on real GDP. Further, farm output will tend to decline in Japan and the US and increase in Australia. The output of the electricity sector, one of the largest sources of $\mathrm{CO}_{2}$ emissions, will tend to increase in Japan and India, and decrease in China, Australia, the US, and the EU.

As for our main research question, the GHG emission impact results show that the RCEP is likely to "increase" the total amount of GHG emissions in the 16 RCEP members and the world. We observe increases in the amount of $\mathrm{CO}_{2}$ emissions in the non-agricultural sectors in each economy, and a substantial increase in the amount of $\mathrm{CH}_{4}$ and $\mathrm{N}_{2} \mathrm{O}$ emissions in the Australian cattle sector.

Finally, we briefly note the limitations of our study as a means of informing future research. In our model, we did not include the changes in environmental policy that may also result from the RCEP. In addition, because of limitations in the available data, we included only $\mathrm{CO}_{2}, \mathrm{CH}_{4}, \mathrm{~N}_{2} \mathrm{O}$, and F-gases as $\mathrm{GHG}$ emissions.

\section{Acknowledgements}

This work was supported by JSPS KAKENHI Grant Numbers JP26252036, JP16H06202.

\section{References}

[1] Australian Department of Foreign Affairs and Trade (ADFAT) (2014) Regional Comprehensive Economic Partnership Negotiations. http://www.dfat.gov.au/fta/rcep/

[2] Ando, M. (2008) Economic Effects of an ASEAN + 6 Free Trade Agreement: A CGE Model Simulation Analysis. Asia Research Report 2007. https://www.jcer.or.jp/eng/pdf/asia07 ch1.pdf

[3] Fukunaga, Y. and Isono, I. (2013) Taking ASEAN+1 FTAs towards the RCEP: A Mapping Study. http://www.eria.org/ERIA-DP-2013-02.pdf

[4] Heagney, K.J. (2013) The RCEP (Regional Comprehensive Economic Partnership) and the Possible Impact of the RCEP on Lao PDR.

http://www.t4dlaos.org/index.php/en/online-resources/category/47-eif-publications?download=174:regional-comprehe nsive-economic-partnership-final-report-27-feb-2013

[5] Lee, H. and Itakura, K. (2014) TPP, RCEP, and Japan's Agricultural Policy Reforms. OSIPP Discussion Paper, Osaka School of International Public Policy, Osaka.

[6] Hertel, T.W., Ed. (1997) Global Trade Analysis: Modeling and Applications. Cambridge University Press, Cambridge.

[7] Lee, H.L. (2008) An Emissions Data Base for Integrated Assessment of Climate Change Policy Using GTAP. https://www.gtap.agecon.purdue.edu/resources/res_display.asp?RecordID=1143 


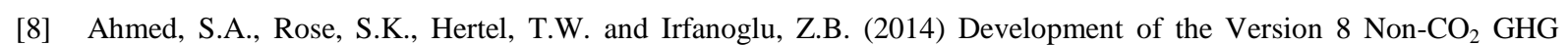
Emissions Dataset. https://www.gtap.agecon.purdue.edu/resources/res_display.asp?RecordID=4343

[9] Rose, S.K. and Lee, H.L. (2009) Non- $\mathrm{CO}_{2}$ Greenhouse Gas Emissions Data for Climate Change Economic Analysis. In: Hertel, T.W., Rose, S.K. and Tol, R.S.J., Eds., Economic Analysis of Land Use in Global Climate Change Policy, Routledge, London, 89-120.

[10] Akahori, H., Masuda, K. and Yamamoto, Y. (2014) Agricultural Nutrient Balances under a Japan-China-Korea Free Trade Agreement: Nitrogen and Phosphorus. Journal of Rural Problems, 50, 60-64. http://dx.doi.org/10.7310/arfe.50.60

[11] Thomassin, P.J. and Mukhopadhyay, K. (2008) Impact of East-Asian Free Trade on Regional Greenhouse Gas Emissions. Journal of International and Global Economic Studies, 1, 57-83.

http://www2.southeastern.edu/orgs/econjournal/index_files/JIGES\%20DEC\%2008\%20GREENHOUSE\%20GAS\%20 EMISSIONS\%20PAPERJIGES(REVISED)\%203-2-09\%20RV1.pdf

[12] United States Environmental Protection Agency (2012) Global Anthropogenic Non- $\mathrm{CO}_{2}$ Greenhouse Gas Emissions: 1990-2030.

https://www3.epa.gov/climatechange/Downloads/EPAactivities/EPA_Global_NonCO2_Projections_Dec2012.pdf

Submit or recommend next manuscript to SCIRP and we will provide best service for you:

Accepting pre-submission inquiries through Email, Facebook, LinkedIn, Twitter, etc.

A wide selection of journals (inclusive of 9 subjects, more than 200 journals)

Providing 24-hour high-quality service

User-friendly online submission system

Fair and swift peer-review system

Efficient typesetting and proofreading procedure

Display of the result of downloads and visits, as well as the number of cited articles

Maximum dissemination of your research work

Submit your manuscript at: http://papersubmission.scirp.org/ 